Archives de sciences sociales des religions

135 | juillet - septembre 2006

Réveils du soufisme en Afrique et en Asie

\title{
What is left of Sufism in Tablîghî Jamâ‘at?
}

\section{Marc Gaborieau}

\section{CpenEdition}

\section{Journals}

Electronic version

URL: http://journals.openedition.org/assr/3731

DOI: 10.4000/assr.3731

ISSN: $1777-5825$

\section{Publisher}

Éditions de l'EHESS

\section{Printed version}

Date of publication: 1 September 2006

Number of pages: $53-72$

ISBN: 2-7132-2093-9

ISSN: 0335-5985

\section{Electronic reference}

Marc Gaborieau, « What is left of Sufism in Tablîghî Jamâ'at? », Archives de sciences sociales des religions [Online], 135 | juillet - septembre 2006, Online since 16 October 2009, connection on 30 April 2019. URL : http://journals.openedition.org/assr/3731; DOI : 10.4000/assr.3731 


\section{Marc Gaborieau}

\section{What is left of Sufism in Tablîghî Jamâ'at?}

Studies published on Islamist and other proselytizing Muslim transnational movements, which became conspicuous in the West from the early 1980s, fail to understand their real significance for two reasons: they lack a long enough historical perspective, ${ }^{1}$ concentrating mainly on the past twenty five years; they do not have access to the historical sources concerning these movements (Kepel, 1987; 2000a; Roy, 2002). This paper argues, on the single example of the Tablîghî Jamâ'at, that a consideration of the history of these movements over a span of now eight decades is necessary for a proper interpretation. It is part of a larger research project on the transformation of South Asian Islam since the 1920s (Clémentin-Ojha, Gaborieau, 1994; Gaborieau, 2001a), which will eventually culminate in a book.

Tablîghî Jamâ‘at is a Muslim missionary movement founded in India around 1927 by Muhammad Ilyâs Kândhalawî (1885-1944); it has now grown into a global organization, with its centre in Delhi ${ }^{2}$ and branches all over the world (Troll, 1985, 1994; Gaborieau, 1997, 1998, 2000; Masud, 2000). ${ }^{3}$ It aims first at comforting the faith of the people who are already Muslim, and secondarily to win new converts to Islam.

1. For more general considerations on the necessity of a longer historical perspective, see Gaborieau, Zeghal 2004.

2. The statement of Gilles Kepel according to which "in the 1960s, the Tabligh displaced its operational centre from Delhi to Raiwind near Lahore in Pakistan" (KePel 2000a, p. 43) is mistaken: Raiwind is just a national centre for Pakistan, as is Tongi near Dhaka for Bangladesh. Nizamuddin near Delhi remains "The Centre" (markâz) where the global leadership resides (Masud 2000: 29).

3. The bibliography appended to this article contains only the publications I have specifically used to write it. For extensive bibliographies see Gaborieau, 1997 and MAsud, 2000. The last mentioned book - the most comprehensive on the subject to this day - was the outcome of an international symposium organized by the SSRC in London in 1990 and contains papers by most of the renowned specialists of the movement: they include, in addition to the editor, who deals with the history and ideology of the movement, and myself describing its global expansion, Barbara Metcalf on Tablîgh and Women (see also Metcalf, 1993), Elke Faust on Germany, Mohamed Tozy on Morocco (see also Tozy, 1999), Felice Dassetto - best scholar on the sociology of the movement - on Belgium (see also DASSETTO 1988), Gilles Kepel on France (see also KePel, 1987 and 2000a), Shaheen Azmi on Canada (see also Azmi, 1989). 
The relation of Tablîghî Jamâ'at to Sufism is a key question to understand the nature and significance of the movement, because it has a bearing on the commitment of the members and on the nature of the leadership. It is also a vexed question: authors have made conflicting statements.

There are first candid assessments which answer the question by 'yes' or 'no'. On the one side are those who think that it is a Sûfî organization. For instance, Muhammad Anwârul Haq, who published the first dissertation about the movement (Haq, 1972), portrayed it as a direct continuation of medieval Sufism, which he believed to have been the main agency of conversion to Islam in India. On the other side stand those who deny the movement any Sûfî connection: "Tabligh is as much opposed to the traditional Islam of the Sûfî Brotherhoods and of the mystics - it condemns as idolatry the cult of tombs common in popular devotions - as it is to the 'politicization' of religion which was brought about by Maududi, Qutb, Khomeini and their successors" (Kepel, 2000a, p. 42). Both sweeping assessments are mistaken: if the movement is not Sûfî, it cannot be said that it is completely devoid of Sûfî elements; in the same way that it cannot be considered as devoid of political implications (Gaborieau, 1997, p. 220-222; 1999). Such naïve statements ignore the complexities of historical reality.

The debate has to be properly mapped. It is a fact that Muhammad Ilyâs, the founder of Tablîghî Jamâ'at, was a charismatic Sûfî belonging to the Chishtiyya order, as emphasized by the first scholarly study of his movement (Troll, 1985, p. 142; 149); the headquarter of his movement is in Delhi, next to the most important Sûfî shrine of the town, the Nizamuddin Dargâh (Jeffery, 1981 and 1981; Gaborieau, 2005), built around the tomb of Nizâmu'd-Dîn Awliyâ (d. 1325). The latter was the most prestigious representative of the Chishtiyya order (Ernst, Lawrence, 2002), which he turned into a pan-Indian institution. This Sûfî connection of Tablîghî Jamâ'at is established beyond doubt.

Then a first preliminary question arises: which kind of Sûfî practices did the movement inherit? It was a reformed one, as re-defined by the Deobandî school (Metcalf, 1982, p. 157-197; Ernst, Lawrence, 2002, p. 95-96, 114, 120).

Our main question can now be redefined in the following wording: how can we assess the extent of reform? Was it a return to the pristine spirit of Sufism purified of later corruptions, as Anwârul Haq would have it (Haq, 1972, p. 173)? Was the reform, on the contrary, so thorough that nothing is left of the substance of Sufism, and that Tablîghî Jamâ'at has to be defined in terms of reform of Islam, not of Sufism? The most recent historical studies lean to this second answer: for instance Khalid Masud thinks that Tablîghî Jamâ'at "does not seem to be a Sûfî movement ... It is more in line with the Ulamâ's reformist activities" (Masud, 2000, xl); the most recent book on the Chishtiyya Sûfî order plainly says: "In the case of ... Tablîghî Jama'at, reformism amounted to a sublimation and simplification of Sûfî piety. In the end, the Tablîghîs rejected institutional Sufism altogether” (Ernst, Lawrence, 2002, p. 107). 
In spite of such very considered historical arguments, there are still scholars who insist on treating Tablîghî Jamâ'at as a Sûfî movement. Such is the case for instance of a recent sociological research in France (Khedimellah, 2001) which argues that it is an hybrid between a reform movement and a Sûfî brotherhood and that it still maintains a mystical spirituality. My colleague and friend Dietrich Reetz, whose paper is published in this issue, arrives to similar conclusions after fieldwork in India. I myself leaned in the same direction in my first inadequate unpublished paper on the subject (Gaborieau, 1986) where I defined Tablîghî Jamâ'at as a familial Sûfî order; but after a thorough study of the history of this movement and a careful reading of the reports of fieldwork then available, I eventually joined this second camp and considered that it had not preserved the characteristics of a mystical organization (Gaborieau, 1997, p. 217). I want here to come back to the mainline of my argumentation: for more details, the reader may see the bibliography.

Of course, my argumentation presupposes a definition of Sufism. For me it is not enough to invoke moral and spiritual qualities like sincerity of intention, scrupulous observance of exoteric religious obligations like prayers, performance of supererogatory devotions and ascetic practices like the forty days retreat. To speak rightly of Sufism one must include individual initiation and spiritual direction by a guide, and the presence of ecstatic feature which are conceived of as transitory union with God. If these elements are absent, one may speak of survival of isolated features, but not of Sufism as such.

But before starting, I delimit the nature and the scope of my sources.

Although I did not do myself much fieldwork about Tablîghî Jamâ‘at, I am far from ignorant of the concrete ways it operates: I visited the general headquarter of the movement in Delhi in 1984, 1993, 1994 and 2002; I met Tablîghî leaders in Chittagong (Bangladesh) in 1993, in the Réunion island in $1998,{ }^{4}$ and in Jakarta in 2003. I have also been a thorough reader of the field accounts so far published (in the chronological order of the first publication of each author) by Partap Aggarwal (1971), Mohamed Tozy (1984, 1999 and 2000), Gilles Kepel (1987 and 2000b), Felice Dassetto (1988 and 2000), Shaheen H. Azmi (1989 and 2000) Barbara Metcalf (1993 and 2000), A. Moustapha Diop (1994), Philip Lewis (1994), Shail Mayaram (1997), Elke Faust (2000), Moussa Khedimellah (2001), Yoginder Sikand (2002) and Marie-France Mourrégot (2004). It might be objected that my stand on the question of Sufism comes from my neglect of field accounts in favour of the written sources, while keen observers in the field, like Moussa Khedimellah and Dietrich Reetz, were able to perceive a mystical dimension which does not come into the written texts. This does not hold good, for the majority of the field reports and of my own observations, far from describing a mystical atmosphere, insist rather on the totalitarian pressure of the movement on the members, which has been best analyzed by Felice Dassetto.

4. I thank my doctoral student Marie-France Mourrégot for introducing me to the Tablîgh leaders of the island (see MourréGot, 2004). 
For my argumentation, which is mainly historical, I rely first of all on sources written in Urdu, which emanate almost exclusively from the movement itself (for an assessment, see Gaborieau, 2000, p. 122-124). ${ }^{5}$ They are of two kinds. There are first historical works which are available only in Urdu: biographies of the leaders of the movements (Bijnaurî, 1980; Hasanî, 1967; Nadwî, 1972 and 1979; Sahâranpûrî, 1997-1999) and the official history of the Nadwatu'l-'ulamâ, an institution of learning based in Lucknow which, under the leadership of the famous Abû'l-Hasan 'Alî Nadwî (1914-1999), participated in the building and expansion of the movement (Khan, 1984). Secondly, I used doctrinal texts which are available not only in their Urdu original, but in the major international languages, English, French, Arabic and Turkish; they are included in the Tabligh $\hat{\imath}$ nisâb, a compendium of eight textbooks, all written by Muhammad Zakariyâ (1898-1982, see Nadwî 1972 and Gaborieau 1992), which are compulsory readings for the Tablîghîs (Muhammad Zakariyâ Kândhalawî, 1938 and n.d.; for a presentation of the whole compendium see Gaborieau, 1992, p. 20 and Masud, 2000, p. 80-85). This historical research has been presented in detail in my seminar at the EHESS during the scholastic year 1985-1986. ${ }^{6}$

In the first part of this paper I will examine the arguments, generally taken from the origins of its leadership, which are generally adduced to characterize Tablîghî Jamâ'at as a Sûfî movement. The two following parts will then deal with the features which militate against such a characterization: the second part will analyze, from historical sources, the central ideology of the movement as formulated by its leaders to see whether it has something to do with Sufism; the third part will look not only at the leadership, but also at the rank and file of the movement to see whether the common member of the Tablîghî Jamâ'at has preserved enough of Sûfî practices to allow us to characterize it as a Sûfî movement. In the concluding remarks, I will raise a further question: if Tablîghî Jamâ'at is not a Sûfî movement, why is it that a Sûfî legitimization is so often claimed for it? Is not this erroneous perspective linked with other common misinterpretations, which deny the movement any kind of political implication and of interest in religious conflicts?

\section{A familial Sûfî order?}

The leadership of the movement, as we have remarked when speaking of its founder, Muhammad Ilyâs, is clearly marked by his Sûfî ancestry: what has it kept of this spiritual heritage?

5. I thank Christian Troll whose work (1985 and 1994) was of a great help to read and interpret these sources, and Khalid Masud, who shared his immense knowledge of the movement and procured me books in Urdu printed in Pakistan as well as oral information collected from Tablîghî leaders.

6. Felice Dassetto and Gilles Kepel, who had just started their work on Tablîghî Jamâ'at, were among those who came to me at that time to get information on the history of the movement. 


\section{A lineage with a Sûfî Tradition}

A striking fact is to be stressed at the start. All leaders of the movement, since its foundation almost eighty years ago, were members of the same endogamous lineage of the Kândhalawîs, named from the ancestral qasba of Kândhala in Northern India, not far from Delhi. They are Siddîqî Shaikhs, i.e. they claim an Arab ancestry going back to the caliph Abu Bakr as-Siddîq; they are classified in the local society as "nobles", ashrâf, belonging to the higher Muslim classes, by contrast with local converts who make up the lower classes and are traditionally designated by their caste names. After the death of Ilyâs, the movement was headed successively by his son Muhammad Yûsuf (1917-1965), his grand-nephew (through his sister's son) In'âmu'l-Hasan (1918-1995) and then by a triumvirate comprising a grandson of Yûsuf, Muhammad Sa'ad, a son of In'âmu'l-Hasan called Zubairu'l-Hasan and a great-grand-nephew (?) of Ilyâs, Izhâru'l-Hasan (Masud, 2000, p. 19). Zubairu'l-Hasan died in 1996; and from the early 2000s it became clear that Muhammad Sa'ad was emerging as the most charismatic leader and the real chief of the movement (Dietrich Reetz, personnal communication); so, after a diversion through a parallel line with In'âmu'l-Hasan, the leadership has returned to the direct descent line of Ilyâs. In addition, Muhammad Zakariyâ (1898-1982), the main ideologue of the movement, the author of the Tabligh $\hat{\imath}$ nisâb, was a parallel paternal first cousin of Ilyâs; he married a daughter of the latter; two of his daughters married Yûsuf and In'âmu'l-Hasan respectively. This is a really endogamous patri-lineage: these details were collected in the biographical literature (summarized in Gaborieau, 1992); to those data must be added those contained in the most recent biography (Sahâranpûrî, 1997-1999, including an incomplete genealogical chart on the first unpaginated leaf after the title page of vol. 1).

The leaders also shared the same mystical tradition. Ilyâs, like most of the Indian Muslims, had multiple Sûfî affiliations: the four great silsilas (Chishtiyya, Suhrawardiyya, Qâdiriyya and Naqshbandiyya) into which he was initiated by Rashîd Ahmad Gangohî (1829-1905), one the founders of Deoband. The SâbiriyyaChistiyya sub-order (Ernst, Lawrence, 2002, p. 118-127) was considered his main affiliation: his connection to it went back to the famous Hâjjî Imdâdu'Llâh (1817-1899) (Metcalf, 1992, p. 9-10) after whom the sub-order divided into two lines: "those to whom he himself had given spiritual authority as Sûfîs (khilâfat) and those to whom he gave permission, at their request, to spread the message of religion (tabligh-i dîn)", but who greatly differed from him in matter of Sûfî metaphysics and worldview (Ernst, Lawrence, 2002, p. 119-120); Ilyâs, through Rashîd Ahmad Gangohî, belonged to this second line. This difference between the two lines is to be kept in mind if we are to understand the real nature of the shaky connection of Tablîghî Jamâ'at with Sufism; we will return presently to this point. The whole family is thus considered as a branch of this particular line of the Sabiriyya sub-order (see chart in Haq, 1972, p. 184-185). As in many Sûfî brotherhoods, succession to the office of chief (amîr) of the movement is 
believed not to pass necessarily from father to son; it is conceived as a heavenly election, a transference of charisma called intiqâl-i nisbat, which may fall on the son, or on a collateral, but apparently cannot go outside the lineage. As seen earlier, with the present pre-eminence of Muhammad Sa'ad, the leadership has safely come back to the direct descent line of the founder!

\section{Sûfî charisma}

To explain the popularity of the movement, several scholars invoked its connection with Sufism. Ilyâs, who lived for years as a recluse in Nizamuddin, acting as a spiritual guide and as a madrasa teacher before founding his movement, was considered to be one of the most influent Sûfîs of his time:

In his correspondence and his sayings (malfâzât) Ilyâs comes across (sic) as an ascetic and a man of genuine mystical experience (Troll, 1985, p. 149).

In spite of his shyness and his stumbling pronunciation (Troll, 1985, p. 142), he possessed a great authority and radiated a remarkable charisma, which is considered to have passed on to his son Yûsuf after his death. From these descriptions of the founder and his son by their biographers, commentators built an explanation of the success of the movement by the Sûfi charisma attached to the founding lineage, and passed from one incumbent to the next (Haq, 1972; Troll, 1985; Gaborieau, 1986).

\section{Sûfî terminology and practices}

In the literature of the Tablîghî Jamâ'at, there are frequent references to Sufism in general terms; and, more concretely, as noted by Anwârul Haq, to technical words designating religious practices specific of Sufism. For instance, Ilyâs himself used to describe his movement as a "moving hospice (khânqâh)" (Nadwî, 1979; Troll, 1985, p. 149). His cousin Zakariyâ speaks in laudatory terms of these hospices and their inmates, the Sûfîs, who are ceaselessly busy in the "remembrance (dhikr)" of Allah: "Nowadays those who confine themselves in the 'Khânqâhs' (sanctuaries) are laughed at (...) The value of these 'Khânqâhs', which are the target of criticism from all sides, can be found from the 'Hadith' which tells us the virtue of Remembrance ('Dhikr')" (Muhammad Zakariyâ Kândhalawî n.d., p. 42; see Masud, 2000, p. 84).

More specifically, technical terms referring to Sûfî religious practices come often, in particular $d h i k r$ to which the first part only of the book wearing this title is devoted (op. cit., p. 1-76). But most of these pages speak of it in quite general terms, in its non-technical meaning of "remembrance", which is not specifically Sûfî. There are however some places (op. cit., p. 46, 57, 61) where the allusion is clearly to the technical sense of this particular Sûfî exercise, which consists in the rhythmical repetition of the names of God with breath control in order to induce ecstasy (Trimingham, 1971, p. 194-207; Popovic, Veinstein, 
1996, p. 150-152, 160-166, 621; Ernst, Lawrence, 2002, p. 27-34). For instance, Zakariyâ wrote: "A shaikh selects for his disciples the type of 'Dhikr' which he thinks more suitable in accordance with their spiritual status" (op. cit., p. 57). The technical term of murâqaba, "contemplation" or "meditation", a practice linked with $d h i k r$ is also often quoted (for instance op. cit., p. 55). Finally Anwârul Haq mentioned chilla, a forty days retreat (khalwa) - the Persian term equivalent to the Arabic arba'îniyya (see Trimingham, 1971, p. 187 and 190: Popovic, Veinstein, 1996, p. 617) - as a Sûfî practice preserved in the Tablîghî Jamâ'at.

Thus the founding lineage shares a common line of initiation, is endowed with Sûfî charisma and teaches the members some Sûfî practices. The addition of all these features made Anwârul Haq and Christian Troll think that Tablîghî Jamâ'at was to be considered as a Sûfî movement:

Among the six points or principles to which the movement remains strongly committed, $d h i k r$ and ikblâs-i niyyat (sincerity of intention) for instance, form an obvious, essential link with Sufism (Troll, 1985, p. 149).

Following this lead, I myself considered that the Kândhalawî lineage was familial Sûfî order; and that the movement itself was a new kind of Sûfî order (Gaborieau, 1986, p. 2, 8-10, 14).

\section{Historical circumstances: A peaceful jihâd?}

My perception got progressively modified when I began to reflect on the historical circumstances of the foundation and expansion of the movement. I started to ask myself, with increasing scepticism, whether there were Sûfî motivations for the foundation of Tablîghî Jamâ‘at. Anwârul Haq (1972) had postulated such a connection: following the thesis of Thomas Arnold (1996), he construed medieval Sûfîs as "missionaries" (sic) who converted Hindu lower classes to Islam; he believed Tablîghî Jamâ'at to be the natural continuation of this medieval $d a^{\prime} w a$ or proselytism. Such a representation of medieval $d a^{\prime} w a$ has no grounding in history (Lawrence, 1984); active proselytism in India by Hindus as well as by Muslims is a recent phenomenon which started in the $19^{\text {th }}$ century to counter and emulate protestant missionaries (Clémentin-Ojha, Gaborieau, 1994).

\section{Tablîghî Jamâ‘at and Deobandî activism}

The direct connection of Tablîghî Jamâ'at is not with Sufism, but with the Deoband school, which had proselytizing activities long before the foundation of the Tablîgh movement (Gaborieau, 1993): all the leaders of the latter were trained in the Deobandî school of thought, and borrowed from it not only their Sûfî affiliations, but first of all their interpretation of reformed exoteric Islam which has been recently well analyzed (Metcalf, 1982, p. 138-157 and 1990). Tablîghî Jamâ'at is only one of the elements of the vast and varied Deobandî 
constellation, with all its teaching and proselytizing activities, which include not only peaceful segments, but also militant "jihâdist" madrasas as recent events in Afghanistan and Pakistan have recently shown: an recent analysis of this connection with Deobandî networks in India has been recently published (Mayaram, 1997, p. 221-254). Deobandîs have always been an activist minority with militant political involvement, contrary to their Barelwi rivals (Sanyal, 1996) who were a quietist but most often silent majority much more preoccupied with Sufism as we shall see later.

The founder of Tablîghî Jamâ'at, Muhammad Ilyâs, was not himself free from this political involvement. He studied in Deoband at the time when the Indian national movement was gaining momentum. His biographers recall that, when he went to Deoband in 1908 to complete his education in hadith under the famous Mahmûdu'l-Hasan (1851-1920) who was also an important nationalist leader, the latter made him take the oath of jihâd (Haq, 1972: 85; Gaborieau, 1992, p. 16). So the climate in which the Tabligh movement was born was not at all one of pacifism, nor even of purely defensive jihâd; in the milieu of Muhammad Ilyâs, holy war with the sword was considered an essential duty of Islam. These preoccupations did not leave him when he lived as recluse in Nizamuddin and launched the Tablîgh movement: it is symptomatic that the only text he widely publicized - and which was published in English just after his death - was a proclamation addressed to political leaders on the eve of independence (Ilyâs, 1944). There was thus a clear, albeit implicit, involvement of Ilyâs in politics.

\section{Religious conflict, fundamentalism, proselytism in the 1920s}

The founding of Tablîghî Jamâ'at is even more closely linked to political events. Its timing is not innocent. The 1920s were a time of effervescence everywhere in the Muslim world (Dupont, Mayeur-Jaouen, 2001): it is the time when, in particular, the Muslim Brothers were founded in Egypt. This was also the case in India (Gaborieau, 2001a): these years witnessed the birth of both Hindu (Jaffrelot, 1996, p. 11-79) and Muslim (Nasr, 1996, p. 9-26) fundamentalism: these events were linked with the deepening divide between the two religious communities following the collapse of the Khilâfat movement (1919-1921) when Hindus and Muslims briefly united against the British under the patronage of Gandhi. Note that the first book of Maududi (1903-1979) on jihâd conceived as an all out offensive war, which marked the birth of Muslim fundamentalism, appeared first in instalments in a Deobandî journal in 1927 (Nasr, 1996, p. 23), precisely in the year which is generally taken as the birth date of Tablîghî Jamâ'at: as emphasized in a recent study (Nasr, 1996, p. 5-6 and passim), HinduMuslim conflict, or communalism as it is labelled in the Indian subcontinent, was Maududi's main incentive. Such was also the case for Ilyâs when he founded his movement: Hindus revivalists had by then launched a campaign of shuddhi, literally "purification", which meant a re-conversion to Hinduism of Muslims 
descended from converts (Clémentin-Ojha, 1994; Jaffrelot, 1994; Mayaram, 1997, p. 65-66). Muslims retaliated by founding all over India numerous tabligh organizations to defend their own community from "apostasy" (irtidâd), as these re-conversions were labelled by them (Hasan, 1991, p. 225-238):

In the 1926, when the shuddhi and tabligh movements were at their height, it was common for Malkanas (a caste of Muslim converts in Rajasthan) to be converted and reconverted to Hinduism in rapid succession. It was said that many of them made quite a lot of money out of their conversion and reconversion (Hasan, 1991, p. 233 n. 81).

Tablîghî Jamâ'at was only one of these many proselytizing movements; but it was the only one to survive this troubled decade. It was thus born from HinduMuslim conflict and from proselytizing competition between the two communities in conflict: Ilyâs used to say that there were two threats for the Muslim community: missionary movements like shuddhi, and secularization (quoted in Masud, 2000, p. 99).

It cannot therefore be said that the discourse of Tablîghî Jamâ'at on other religious communities is irenic and only aimed at facilitating religious coexistence. The movement was born out of conflict; and the defence of the community and of its religious boundaries is central in its motivations, as it is central in the whole Deobandî tradition. Thus, born in time of Islamic reassertion and deepening religious conflict, Tablîghî Jamâ‘at is a militant fundamentalist movement.

\section{Tablîghî Jamâ'at and politics}

What characterizes Ilyâs and his organization - in contrast with Maududi is that this reassertion was from the beginning to the end divorced from the quest for a national state: Ilyâs had from the start a global ambition. He tried before his death to implant his movement in the Arabic peninsula, to turn Arabs into good Muslims - thus implying that they were not! It is no surprise that the Saudi authorities refused permission. However this episode means that the global expansion of the movement under his son Yûsuf (Gaborieau, 2000) was no innovation, but a logical consequence of the ideology of Ilyâs. Before pondering at the strategy of this global expansion, let us look at its political implications.

It is often said that the movement is a-political, because open discussions of political matters are prohibited inside the movement, for the reason that they prove divisive - as are theological discussions which are also outlawed. And the organization, as such, does not take political position, even for the defence of Muslim causes such as Kashmir, Palestine or Bosnia, for fear of confrontation with governments. But this does mean that the members cannot have privately political commitments and activities - a point which we will not develop here. It does not mean either that the strategy of the movement is devoid of political implications. It has first clear ideological commitments: Ilyâs, imbued with the traditional Islamic conception of time conceived as a continuous degeneration from the pristine perfection of the Prophetic era, did not believe in the modern 
conception of progress; the only way of progressing for the Muslims was to imitate the Prophet and to obey the holy Law. It follows that secularization and westernization are considered as evils, and that Islam must command all the aspects of life (see Masud, 2000, p. 86-90). Tablîghî Jamâ'at has, in the second place, a vision of the political future of the Muslim community, not in the short run through the conquest of State power as Maududi believed, but in the long run: the accumulation of individual efforts toward religious perfection will finally empower the Muslim umma; for Ilyâs believed, as ably stated by Christian Troll, that perfect implementation of Islamic rituals and holy Law were "leading ultimately to the establishment of Islamic political structures" (Troll, 1994, p. 129). Political aims are included in the means; they are not to be sought for; they will come in addition. In this way "it cannot therefore be concluded that Mawlânâ Ilyâs had no political vision and agenda" (Masud, 2000, p. 99). Or, to put it another way, it has been emphasized that,

this total faith is extended into the attitude toward politics which is as neutral as it is radical... (For the Tablîghîs), the very radicalism of their faith and their models of reference are powerful critiques of existing political systems, particularly those claiming to be Islamic... They go to the heart of the problem of power in "Muslim" countries without touching it (Dassetto, 2000, p. 175).

Recent research has shown that the growing involvement of the Tablîgh movement in politics in Pakistan (Gaborieau, 1997, p. 222). A careful analysis of the Indian situation (Mayaram, 1997, p. 234-248) by an anthropologist has emphasized these political implications. It cannot therefore be said that Tablîghî Jamâ'at has no political agenda (Gaborieau, 1999).

\section{A peaceful ?}

How to prepare the Muslim umma for this end? It is striking that the most common terms which run over all the accounts of the spread of the movement turn around the concept of jihâd, or sacred struggle in the way of Allah. The lead was given by Ilyâs himself who declared:

The travel (for Tablîgh) has the same characteristics as the raids (ghazwât) (in jihâd), and therefore we hope to earn the same reward. Even though it does not constitute "physical fighting with weapons" (qitâl), it is still a branch of jihâd. It is lower than qitâl in some respects, yet it is higher in certain respects (Quoted in Masud, 2000, p. 105).

The accounts of the spread of the movement in the biographical literature (Gaborieau, 2000) are literally presented as a conquest of the world, in the military vocabulary of classical jihâd, with raids, sallies (khurûj), patrols (gasht or jaula).

This jihâd, as in the words of Ilyâs quoted above, is usually described as peaceful. But the spirit remains military. It is therefore not a coincidence that in the recent past, Tablîgh mosques in Europe, or in India and Pakistan were an 
avenue to more militant organizations which recruited fighters for Afghanistan, Kashmir or Bosnia... Such a transition is not so far from the principles of Tablîgh: for, if the movement as such does not admits fighters in its ranks, it does agree - as do all Deobandîs - on the classical theory of offensive holy war. Their jihâd is not totally peaceful in spirit. As it is well known now, it is only in an older proselytizing movement, that of the Ahmadiyya, that the classical theory of holy war was renounced in favour of totally peaceful conception of preaching (Friedmann, 1989, p. 165-186; Gaborieau, 1996).

Far from being a continuation of the Sûfî tradition, Tablîghî Jamâ'at is from the start linked to Deoband from which it inherited a spirit of militancy which expressed itself - at a time a religious conflict - in the creation of a proselytizing movement for the defence of the Muslim community not only in India, but in the whole world. This movement had political implications in its ideology and in its ultimate ends. It was informed by the ideology of the holy war, or the fight in the path of Allah, in which collective action had precedence over the individual itinerary of mystic.

\section{Doing away with institutional sufism: brotherhood or "sect"?}

What this militant program of reform did really have to do with Sufism? Has the Sûfî inheritance of the founding members been substantially passed into the working of the movement?

\section{Reformed Sufism}

From the outset it should made clear that, as good Deobandîs, the Jamâ'at leaders have done away with all the external practices which characterized traditional Chishtiyya religiosity. Not only do they shun mystical audition, samấ, which in Nizamuddin takes the shape of qawwâlî singing; but they also prohibit the visit of the tombs in the Dargâh complex, and the celebration of annual festivals which are either the Islamic death anniversaries of Nizamu'd-Dîn, of the Indo-Persian poet Amîr Khusrau (1253-1325) and of the Prophet Muhammad, or festivities of Hindu origin like basant in honour of the Spring (on these festivals see Jeffery 1979 and 1981). The Jamâ'at building is towering above the shrine complex. But the Tablîghîs keep aloof from the devotions of the Dargâh, and do not mix with the descendants of the saints who make a living by collecting the offerings of the devotes. The leaders of the Tablîghî Jamâ'at (Muhammad Ilyâs, his father Muhammad Ismâ'îl (1835?-1898), his son Muhammad Yûsuf and his nephew In'âmu'l-Hasan) are all buried together near the headquarter of the movement, but their tombs do not seem to have become an object of pilgrimage. The Tablîghîs thus keep clearly aloof from the most visible institutionalized Sûfî devotions. They clearly abide by the rules of reformed Sufism as defined by the Deoband school. 
64 - Archives de SCIENCES SOCIALES Des REligions

\section{Doing away with internalized Sûfî practices}

Even if they had done away with external practices like tomb pilgrimage, most of the Deobandîs, as Barbara Metcalf has shown from vivid biographical accounts, still adhered to internalized Sûfî practices like $d h i k r$ taken in its real technical sense of an ecstatic technique (Metcalf, 1982, p. 157-197). The leadership of the Tablîghî Jamâ'at, which is made of initiated Sûfîs, may continue such exercises; but this is no part of Tablîgh activities as such. As to the common members of the movement, when they are reminded of the "merits of dhikr" according to the title of the above quoted famous book written by Maulânâ Zakariyâ analyzed above (n.d.), it is only in the more general sense of remembrance of God, not in the technical sense of an ecstatic ceremony we have mentioned earlier; in their gatherings the Tablîghîs do not seem to have ecstatic exercises; at least they are not reported in the literature I have read. Similarly, when they speak of chilla, they do not mean a solitary forty days retreat, leading to a spiritual and even often ecstatic experience, but a collective preaching tour for the same period of time.

Thus, while the leadership and selected members of the movement may be full-fledged Sûfîs initiated by spiritual guides and trained to such ecstatic practices in their internalized forms, the common member does not get automatically a mystical initiation. There are thus two features which prevent us from considering Tablîghî Jamâ'at as a Sûfî movement. First a Sûfî order is an "initiatic" institution, into which people are recruited and trained individually: entering Tablîgh movement does not entail such an initiation, and as such is not a Sûfî organization; this first difference has been well expressed by a leading expert on Indian Sufism:

Their Islamic dress code duplicates that of modern revivalist Indian Sûfîs, but without any master-disciple relationship, traditional religious education, Sûfî initiation ritual, or inclination toward spiritual practice (Buehler, 1998, p. 22).

The second feature is the absence of ecstatic elements. For these two reasons, the movement cannot be said to be a Sûfî organization.

\section{"Living}

If the Tablîghîs are no Suffîs, how can we define positively what they are in the content of their religious practices and in the form of their collective action? From the descriptions that have been made of the day-to-day life of the Tablîghîs (the most detailed being Metcalf, 1993), it appears that they are mainly kept busy with exoteric devotions. First of all come, of course, the canonical prayers. Supererogatory devotions and other optional practices, like repeating the kalima and reciting darûd sharîf, come second. And as we have seen in the foregoing paragraph, it is doubtful whether what is called $d h i k r$ in Tabligh has anything to do with the medieval ecstatic practice of the same name. 
The rules to be followed are external ones, not internalized ones. What is mainly taught is to objectively model one's own behaviour on that of Prophet Muhammad. It is not a coincidence that the longest - and almost oldest - book consigned in the Tablighhî nisâb, is the Stories of Compagnons of the Prophet (Hikâyâtu's-Sahâba) that runs to 256 pages in the English translation (Muhammad Zakariyâ Kândhalawî 1938; on this book see Masud, 2000, p. 83). There one will find in minute details how the Prophet acted even in the most trivial circumstances of life. And the main exercise of the Tablîghis, who must know this book almost by heart, is to imitate as closely as possible the Prophet's way of life as known from the Traditions ( hadith) which have been collected, translated and commented in the above mentioned book of Zakariyâ and in similar works. All this resembles little the internalized Sûfî path, and differs little from the Wahhâbî emphasis on following literally the prescriptions of hadith!

\section{A "total institution"}

A striking feature of many field accounts is that they emphasize not only this literality, but also the enormous psychological pressure laid on the people enrolled in Tablîgh teams: this was true particularly of the first thesis on the subject which dealt with Tablîgh in Morocco (Tozy, 1984, 2000 and personal conversation). Similar reports came from Canada (Azmi, 1989 and personal conversation). It was left to Felice Dassetto to theorize on this pressure from his observations in Belgium:

By regulating behaviour, and through its effects on the individual, the Tablîgh functions like a veritable total institution in the manner described by Goffman ${ }^{7}$ (Dassetto, 2000, p. 184; see also Dassetto, 1988, p. 168).

What I have seen in Réunion island, where the Tablîgh organization is rigidly controlled by the richest merchants, resembles much Dassetto's descriptions: as we shall see in the concluding remarks, if we look for Sûfî features in the Réunion, we will find them only among their adversaries who are affiliated to the Barelwî school. Observers of the Indo-Pakistanese scene have often stressed that Tablîgh exercices also a high pressure on the time and on the money of its adherents, to the extent that that they are often led to neglect their familial obligations. For all these reasons, I followed Dassetto's lead to compare Tablîgh Jamâ'at to what is called a "sect" in French terminology, that is to say an organization that desocializes individuals to keep them under its control (Gaborieau, 1997, p. 222).

To sum up, the Tablîghî Jamâ‘at, deprived of internalized ecstatic Sûfî techniques, conceives of its action not as inward looking and individual as we would expect from a Sûfî organization, but as outward looking and collective

7. The reference is here to E. Goffmann, 1961, Asylums: Essays on the social situation of the Mental Patients and others inmates, New York, Anchor Books, Double Day. 
as we encounter in groups more concerned with building power than with selfimprovement (Gaborieau, 1997, p. 220-223). There is clearly a divorce between on the one side "initiatic" Sûfî institutions - which as we shall see presently are better preserved in the rival theological school of the Barelwîs - and on the other side this missionary movement which has lost all esoteric character and is only interested in reform.

\section{Concluding remarks: in search of legitimation}

In conclusion, the esoteric individual quest and its ecstatic complement, which characterize Sufism, do not constitute an integral part of the Tablîghî agenda: they lie outside it. They are therefore marginal and field accounts show that they are absent in most of the cases. Tablîghî Jamâ'at, in the longer perspective of its eight decades old history, appears as a militant collective reform movement to strengthen the global Muslim community in its own religious identity, to tighten the boundaries between Muslims and other religious communities. This religious agenda has political implications: it keeps religious conflicts in its background; it rejects the framework of nation states and militates against secularization and modernization; by making itself present everywhere, it is building power resources.

It might be objected that the reappearance of Sûfî features in some contexts may invalidate my interpretation. Such resurgences have been reported in Turkey and in France for instance: the most elaborated treatment of the reappearance of Sûfî feature has been made in the French context by Moussa Khedimellah (2001) who sees Tablîgh Jamâ'at as an hybrid organization between a reform movement and a Sûfî brotherhood, since its locally favours a revivalist spirituality and a mystical quest for self-reconstruction. Such reappearances are also found in Pakistan and India (see Dietrich Reetz's paper in this volume). But do such facts change the overall interpretation of the movement? First it must be emphasized that such instances are in a minority. But this is not my main objection. My second point is that this argument is anachronistic: it amounts to say that a movement which has been planned and developed since eight decades, and remains highly centralized, can be interpreted only in the light of contemporary localized observations, that is to say that only synchronistic sociology in contexts far away from the origins of the movement can reveal its real nature and significance. In my mind such synchronistic studies enlighten us first and foremost on the local contexts in the present time. The interpretation of the movement as a whole - which is still at work mainly among people present in, or originating from, the Indian subcontinent - can be done, as we have shown in the second part of this paper, only in connection with the political history of the subcontinent since the 1920s, and with some knowledge of the real nature of Sufism in that place. In this light the hard core of the agenda of Tabligh is clearly collective 
action in defence of the Muslim community threatened by religious conflict and secularization. More irenic interpretations, which ignore religious conflicts and underscore collective duties, are, from a historical point of view, misconceptions.

In the Indian subcontinent, and among its diasporas, the institutions of Sufism and the personalized mystic quest have been usually preserved not among the Tablîghîs and, more generally, not among the Deobandîs, but among the rival theological school of the Barelwîs (Sanyâl, 1996) with whom the leadership of the Naqshbandîs has made an alliance (Buehler, 1998). Such is the case for instance in England where the situation has been described at length (Lewis, 1994). In the Réunion island, I found Sûfîs only among the tiny minority of the Barelwîs, while the majority of the local Muslims are Tablîghîs whose institutions are strictly controlled by the richest merchants who have not the least mystical inclination: for instance, the supermarket owner who made the French translation of the Tablighî nisâb - which is printed in Delhi and distributed all over the world was trained in the Wahhâbî "Islamic University" of Medina which is particularly anti-Suffî! For the experts of South Asia, the mystical tradition is considered to be really alive not among the Deobandîs and their Tablîghî allies which belong to the non-mystical line of the Sâbiriyya-Chishtiyya, but among the rival schools roughly classified as Barelwîs, and affiliated either to the other branches of the Chishtiyya (Ernst, Lawrence, 2002, p. 104-127), or to the Qâdiriyya order (Sanyâl, 1996, p. 97-127) or to the Naqshbandiyya (Buehler, 1998).

It remains to see where does this insistence on attributing Tablîghî Jamâ'at a Sûfî character come from. For the Tablîghîs themselves, and for their apologists, Sûfîs have a good reputation; they are thought to be irenic. This label of Sufism is therefore used to ensure the good reputation to the movement, and to divert any accusation of fomenting sectarian dissensions, or of being prone to fundamentalism. It is a problem of legitimization. There are similar difficulties with the vexed question of the political or a-political nature of Tablîgh. In spite of the evidences repeatedly adduced to prove the political implications of the movement, as we have seen in the second part of the paper, Tablîghîs themselves, and their apologists, insist on treating Tablîghî Jamâ'at as totally a-political. This is again to avoid suspicion and ensure the good reputation of the movement. Thirdly, equally problematic is the insistence on presenting Tablîghî as an irenic movement with no hostility whatsoever to religious communities other than the Muslims, ignoring the religious conflict which caused its foundation and religious tensions of the contemporary world: here again religious peace and ecumenical attitudes are the correct behaviour of the day, and the movement has to be portrayed in this way to gain legitimacy. On all these three points, a problem of legitimization is at stake: one wants to create a politically correct image. We are not interested here in such images, but in historical interpretation. 
68 - Archives de sciences sociales des Religions

\section{Bibliography}

Aggarwal Partap C., 1971, Caste, Religion and Power: An Indian Case Study, Delhi, Shri Ram Centre for Industrial Relations.

ARnold Thomas W., 1896, The Preaching of Islam. A History of the Propagation of the Muslim Faith, London, The Westminster Press ( $2^{\text {nd }}$ rev. ed., London, 1913).

Azmi Shaheen H., 1989, “An Analysis of the Religious Divisions in the Muslim Community in Toronto", Al-Basirah, I/1, p. 2-9.

Azmi Shaheen H., 2000, “A Movement or a Jamâ'at?”, in Muhammad Khalid MAsud, ed., Travellers in Faith. Studies of the Tablîghî Jamâ'at as a Transnational Islamic Movement for Faith Renewal, Leiden, E. J. Brill, p. 222-239.

BuEHLER Arthur F., 1998, Sûfî Heirs of the Prophet. The Indian Naqshbandiyya and the Rise of the Mediating Sûfî Shaykh, Columbia, University of South Carolina Press.

BijnAurî 'Azîzu'r-Rahmân, 1980, Tadhkira-yi Amir-i tablîghî Maulânâ Muhammad Yûsuf Dihlawî, Bhera (Sargodha), Dhû'l-Nurain Akâdemî.

Clémentin-OjHA Catherine, "La shuddhi de l'Arya ou l'invention d'un rituel de (re)conversion à l'hindouisme", Archives de sciences sociales des religions, $\mathrm{n}^{\circ}$ 87, JulySeptember 1994, p. 99-114.

Clémentin-OjHa Catherine, Gaborieau Marc, 1994, "La montée du prosélytisme dans le sous-continent indien”, Archives de sciences sociales des religions, $\mathrm{n}^{\circ} 87$, July-September 1994, p. 13-33.

Dassetto Felice, 1988, “The Tablîgh Organization in Belgium”, in Thomas Gerholm, Y. G. Litham, The New Islamic Presence in Western Europe, London, Mansell, p. 59-173.

DASSETTO Felice, 2000, “Tablîghî Jamâ'at in Belgium”, in Muhammad Khalid MAsud, ed., Travellers in Faith. Studies of the Tablighî Jamâ'at as a Transnational Islamic Movement for Faith Renewal, Leiden, E. J. Brill, p. 174-187.

Diop Moustapha A., 1994, "Structuration d'un réseau : la Jamâ‘at Tablîgh (Société pour la propagation de la Foi)”, Revue Européenne des Migrations Internationales, vol. 10, $\mathrm{n}^{\circ} 1$, p. 145-155.

Dupont Anne-Laure, Mayeur-Jaouen Catherine, eds., 2001, Débats intellectuels au Moyen-Orient dans l'entre-deux-guerres, special issue of Revue des Mondes Musulmans et de la Méditerranée, $\mathrm{n}^{\circ}$ 95-98/1.

ERnst Carl W., Lawrence Bruce B., 2002, Sûfî Martyrs of Love. The Chishti Order in South Asia and Beyond, New York, Palgrave Macmillan.

FAust Elke, 2000, "Tablîghî Jamâ‘at in Britain and Germany”, in Muhammad Khalid Masud, ed., Travellers in Faith. Studies of the Tablighî Jamâ'at as a Transnational Islamic Movement for Faith Renewal, Leiden, E. J. Brill, p. 139-160.

FrIEDMANN Yohanan, 1989, Prophecy Continuous. Aspects of Ahmadî Religious Thought and Its Medieval Background, Berkeley, University of California Press.

GaboriEau Marc, 1986, "What is Tablîghî Djamâ‘at? Preliminary Thoughts about a New Strategy of Adaptation to Minority Situations”, Paris, SSRC-CERI workshop on Muslim Minorities (unpublished).

Gaborieau Marc, 1992, "Muhammad Ilyâs Kândhalawî”, "Muhammad Ismâ‘îl Kândhalawî”, "Muhammad Yûsuf Kândhalawî”, "Muhammad Zakariyâ Kândhalawî”, in Marc Gaborieau, Nicole Grandin, Pierre Labrousse, Alexandre Popovic, eds., Dictionnaire biographique des savants et grandes figures du monde musulman 
périphérique, du XIX ${ }^{e}$ siècle à nos jours, Paris, EHESS, La transmission du savoir dans le monde musulman périphérique, fasc. 1, p. 16-20.

Gaborieau Marc, 1993, "The Transmission of Islamic Reformist Teachings to Rural South Asia: The Lessons of a Case Study", in Hassan Elboudrari, ed., Modes de transmission de la culture religieuse en Islam, Cairo, Institut Français d'Archéologie Orientale, p. 119-157.

GaboriEau Marc, 1996, “A peaceful jihâd? Proselytism as seen by Ahmadiyya, Tablîghî Jamâ'at and Jamâ‘at-i Islâmî”, paper presented to the Workshop on Transformations of South Asian Islamicate Community in the $19^{\text {th }}$ and $20^{\text {th }}$ Centuries, Chapel Hill, University of North Carolina, 23-26 May 1996 (to be published in 2006 in a special issue of Jerusalem Studies in Arabic and Islam dedicated as a Festschrift to Yohanan Friedmann).

GaboriEAu Marc, 1997, "Renouveau de l'islam ou stratégie politique occulte ? La Tablighî Jamâ'at dans le sous-continent indien et dans le monde", in Catherine CLÉMENTINOJHA, éd., Renouveaux religieux en Asie, Paris, École française d'Extrême-Orient, p. 211-229.

Gaborieau Marc, 1998, “Tablîghî Djamâ‘at”, Encyclopaedia of Islam, Leiden, E. J. Brill, vol. X, p. 38-39.

Gaborieau Marc, 1999, “Transnational Islamic Movements: Tablighi Jama'at in Politics?” ISIM Newsletter, $\mathrm{n}^{\circ}$ 3, July 1999, p. 21 (Leiden, International Institute for the Study of Islam on the Modern World).

Gaborieau Marc, 2000, “The Transformation of Tablîghî Jamâ'at into a Transnational Movement”, in Muhammad Khalid Masud, ed., Travellers in Faith. Studies of the Tablighî Jamâ'at as a Transnational Islamic Movement for Faith Renewal, Leiden, E. J. Brill, p. 121-138.

Gaborieau Marc, 2001a, “L'Inde de 1919 à 1941 : nationalismes, 'communalisme', prosélytisme et fondamentalisme", Revue des Mondes Musulmans et de la Méditerranée, $\mathrm{n}^{\circ}$ 95-98/1, p. 111-125 (special issue Débats intellectuels au Moyen-Orient dans l'entredeux-guerres, éd. by Anne-Laure Dupont, Catherine Mayeur-Jaouen).

Gaborieau Marc, 2001b, "De la guerre sainte (jihâd) au prosélytisme (da'wa) ? Les organisations musulmanes transnationales d'origine indienne”, in Jean-Pierre BASTIAN, Françoise Champion, Kathy Rousselet, eds., La globalisation du religieux, Paris, L'Harmattan, 2001, p. 35-48.

Gaborieau Marc, 2005, “Un sanctuaire soufi en Inde : le dargâh de Nizamuddin à Delhi”, in Dominique Iogna-Prat, Gilles Veinstein, éd., Lieux de culte, lieux saints dans le judaïsme, le christianisme et l'islam, numéro spécial de la Revue de l'histoire des religions, tome 222, fascicule 4, octobre-décembre 2005, p. 529-555.

Gaborieau Marc, Zeghal Malika, 2004, “Autorités religieuses en Islam”, Archives de sciences sociales des religions, $\mathrm{n}^{\circ}$ 125, January-March 2004, p. 5-21.

HAQ M. Anwârul, 1972, The Faith Movement of Mawlânâ Muhammad Ilyâs, London, George Allen \& Unwin.

Hasan Mushirul, 1991, Nationalism and Communal Politics in India, Delhi, Manohar, $2^{\text {nd }}$ ed. augmented ( $1^{\text {st }}$ ed. 1979$)$.

HASANI Sayyid Muhammad Thânî, 1967, Sawânih-i Hazrat Maulânâ Muhammad Yûsuf Kândhalawî, Lucknow, Maktaba Islamiyya. 
70 - Archives de SCIENCES Sociales des Religions

Ilyas Maulana Muhammad, 1944, A Call to Muslims - Message to an All-India Conference of Ulama, and the Muslim Political Leaders at Delhi in April 1944, the Year of his Death, Lyallpur, Malik Brothers.

JAFFRELOT Christophe, 1994, “Les (re)conversions à l'hindouisme (1885-1990) : politisation et diffusion d'une 'invention' de la tradition”, Archives de sciences sociales des religions, n 87 , July-September 1994, p. 73-98.

JafFrelot Christophe, 1996, The Hindu Nationalist Movement and Indian Politics, 1925 to the 1990s, London, Hurst \& C $\mathrm{C}^{\mathrm{o}}\left(1^{\text {st }}\right.$ French ed. 1993).

JefFery Patricia, 1979, Frogs in a Well. Indian Women in Purdah, London, Zed Press.

JefFery Patricia, 1981, “Creating a Scene: The Disruption of Ceremonial in a Sûfî Shrine”, in Imtiaz Ahmad, ed., Ritual and Religion among Muslims of the Sub-continent, Delhi, Manohar.

KÂNDHALAWI Muhammad Zakariyyâ Hadrat Maulânâ, Shaikh-ul-Hadîth, 1938, Hikâyâtu'sSahâba. English translation: The Stories of Sahaba, revised ed., Delhi, Taj Company/ Islamic Book Trust, 1983 (The longest one - 256 p. - and among the first of the eight textbooks composing the Tablìghî nisâb).

KandHALAwî Muhammad Zakariyyâ, 1938 n.d. (written after 1945), Fazâ‘il-i Dhikr. English translation: Virtues of Dhikr (Remembrance of Allah), Delhi Taj Company/ Islamic Book Trust (Chronologically the last but one of the textbooks included in the Tablìghî nisâb).

Kepel Gilles, 2000a, Jihâd. Expansion et déclin de l'islamisme, Paris, Gallimard.

KePEL Gilles, 2000b, “Foi et pratique. Tablîghî Jamâ'at in France” in M. Khalid MAsud, ed., Travellers in Faith. Studies of Tablîghî Jamâ'at as a Transnational Islamic Movement for Faith Renewal, Leiden, E. J. Brill, p. 188-205.

Khan Shams-i Tabrîz, 1984, Tarîkh-i Nadwatu'l-'ulamâ, vol.2, Lucknow, Daftar-i Nizâmat-i Nadwatu'l-'ulamâ.

Khedimellah Moussa, 2001, "Jeunes prédicateurs du mouvement de la Jama'a Tabligh : la dignité identitaire retrouvée par le puritanisme religieux ?”, Revue de socioanthropologie, septembre-décembre 2001, p. 15-49.

LaWrence Bruce B., 1984, "Early Indo-Muslim Saints and Conversion" in FriedmanN, Yohanan, ed., Islam in Asia, vol. 1, South Asia, Jerusalem, The Magness Press, p. 109145.

LewIS Philip, 1994, Islamic Britain. Religion, Politics and Identity among British Muslims, London, I. B. Tauris.

Masud M. Khalid, ed., 2000, Travellers in Faith. Studies of Tablìghî Jamâ'at as a Transnational Islamic Movement for Faith Renewal, Leiden, E. J. Brill.

Mayaram Shail, 1997, Resisting Regimes. Myth, Memory and the Shaping of a Muslim Identity, Delhi, Oxford University Press.

Metcalf Barbara Daly, 1982, Islamic Revival in British India: Deoband 1860-1900, Princeton, Princeton University Press.

MetCalf Barbara Daly, 1990, Perfecting Women. Maulana Ashraf 'Ali Thanawi's Bihishti Zewar. A Partial Translation with Commentary, Berkeley, University of California Press.

Metcalf Barbara Daly, 1992, “Ashraf "Alî Thânawî”, “'Imdâdu Llâh Thânavî”, "Muhammad Qâsim Nânotawî”, "Rashîd Ahmad Gangohî”, in Marc GABORIEAU, Nicole 
Grandin, Pierre Labrousse, Alexandre Popovic, éds., Dictionnaire biographique des savants et grandes figures du monde musulman périphérique, du XIXe siècle à nos jours, Paris, Éditions de l'EHESS, La transmission du savoir dans le monde musulman périphérique, Fasc. 1, p. 9-10; 13; 17-18; 21-22.

Metcalf Barbara Daly, 1993, "Living Hadîth in the Tablîghî Jamâ‘at", The Journal of Asian Studies, 52/3, August 1993, p. 584-608.

MetCalf Barbara Daly, 2000, "Tablîghî Jamâ‘at and women”, in Muhammad Khalid MAsud, ed., Travellers in Faith. Studies of the Tablighî Jamâ'at as a Transnational Islamic Movement for Faith Renewal, Leiden, E. J. Brill, p. 44-58.

MOURRÉGOT Marie-France, 2004, “Indiens, musulmans et français : les marchands sunnites de la Réunion”, in Véronique Boulluier, Catherine Servan-SChreiber, éds., De l'Arabie à l'Himalaya. Chemins croisés en hommage à Marc Gaborieau, Paris, Maisonneuve \& Larose, p. 273-289.

NADwî Sayyid Abû'l-Hasan 'Alî, 1972, Maulânâ Muhammad Zakariyâ Sâhib, Lucknow, Maktaba Islamiyya.

NADwî Sayyid Abû'l-Hasan 'Alî, 1979, Life and Mission of Maulana Muhammad Ilyas, transl. by Muhammad Asif Qidwai, Lucknow, Academy of Islamic Research and

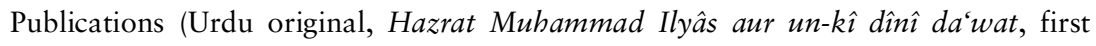
published in 1946).

NASR Seyyed Vali Reza, 1996, Mawdudi \& the Making of Islamic Revivalism, New York, Oxford University Press.

Popovic Alexandre, VeInsteIn Gilles, 1996, Les voies d'Allah. Les ordres mystiques dans le monde musulman des origines à aujourd'hui, Paris, Fayard.

Roy Olivier, 2002, L'islam mondialisé, Paris, Le Seuil.

SAHARANPÛRî Sayyid Muhammad Shahîd, 1997-1999, Sawânih-i Hazrat-jî thâlith, Maulânâ Muhammad In'âmu'l-Hasan Kândhalawî, Sahâranpûr, Maktaba Yâdgar-i Shaikh, 3 vol.

SANyal Usha, 1996, Devotional Islam and Politics in British India. Ahmad Riza Khan Barelwî and his Movement, 1870-1920, Delhi, Oxford University Press.

SIKAND Yoginder, 2002, The Origins and Development of the Tablighi Jama'at, Delhi and Hyderabad, Orient Longman.

Trimingham J. Spencer, 1971, The Sûfî Orders in Islam, Oxford, Clarendon Press.

Tozy Mohamed, 1984, "Champ et contre-champ politico-religieux au Maroc", Thèse, Faculté de droit et de sciences politiques d'Aix-Marseille (inédite).

Tozy Mohamed, 1999, Monarchie et islam politique au Maroc, Paris, Presses de la Fondation Nationale des Sciences Politiques.

Tozy Mohamed, 2000, “Sequences of a Quest: Tablîghî Jamâ‘at in Morocco”, in Muhammad Khalid MASUD, ed., Travellers in Faith. Studies of the Tablighî Jamâ'at as a Transnational Islamic Movement for Faith Renewal, Leiden, E. J. Brill, p. 164-173.

Troll Christian W., 1985, "Five letters of Maulana Ilyas (1885-1944), the Founder of the Tablîghî Jamâ'at, Translated, Annotated and Introduced”, in Christian W. Troll, ed., Islam in India. Studies and Commentaries, vol. 2, Delhi, Vikas, p. 138-176.

Troll Christian W., 1994, "Two Conceptions of da'wa in India: Jamâ'at-i Islâmî and Tablîghî Jamâ'at", Archives de sciences sociales des religions, $\mathrm{n}^{\circ}$ 87, July-September 1994, p. 115-133. 
72 - Archives de sciences SOCIALES Des RELIGIONS

\section{Résumé}

Réfutant les interprétations simplistes à courte vue, cet article replace dans son contexte historique, pour en restituer l'inspiration centrale, la Tablìghî Jamâ'at, mouvement missionnaire musulman transnational né en Inde en 1927. L'angle d'attaque choisi est celui du rapport de ce mouvement avec la mystique musulmane ou soufisme. La première partie expose les interprétations courantes qui font de la Tablighî̀ Jamâ'at un mouvement soufi. Les deux parties suivantes réfutent cette vue simpliste en analysant l'idéologie du mouvement exposée dans les écrits de ses leaders (deuxième partie), et en décrivant la pratique religieuse de ses membres (troisième partie). Il apparaît clairement que les aspects soufis sont résiduels dans ce mouvement qui vise avant tout à encadrer et à discipliner ses fidèles dans une doctrine théologique précise, celle de l'école de Deoband, qui n'est pas dénuée d'arrière-pensées politiques.

Mots-clés : Islam, Inde, prosélytisme, soufisme, politique.

\section{Abstract}

Refuting simplistic and short sighted interpretations, this paper replaces in its historical context, in order to reveal its central inspiration, the transnational Muslim missionary movement called Tablighî Jamâ'at, which was created in India around 1927. The perspective chosen is that of the relationship of this movement to Islamic mysticism, or Sufism. The first part of the paper describes current interpretations which conceive of Tablighî Jamâ'at as a Sîfî organization. The following two parts refute this too simplistic view by analyzing the ideology of the movement as described in the writings of its leaders (second part) and the religious practice of its members (third part). It becomes then evident that Sîfi aspects are residual in this movement, the main aim of which is to discipline its members in the Deobandi theological doctrine which is not devoid of political implications.

Key words: Islam, India, proselytism, sufism, politics.

\section{Resumen}

Refutando las interpretaciones simplistas de corto alcance, este artículo reubica en su contexto histórico, para devolverle la inspiración central, a la Tablîghî Jamâ'at, movimiento misionero musulmán transnacional nacido en la India en 1927. El ángulo de abordaje elegido es el de la relación de este movimiento con la mística musulmana, o sufismo. La primera parte expone las interpretaciones comunes que hacen de la Tablighî Jamâ'at un movimiento sufi. Las dos partes siguientes refutan esta perspectiva simplista, a través del análisis de la ideología del movimiento expuesta en los escritos de sus líderes (segunda parte), y de la descripción de la práctica religiosa de sus miembros (tercera parte). Aparece con claridad el hecho que los aspectos sufis son residuales en este movimiento cuyo objetivo principal es encuadrar y disciplinar a sus fieles en una doctrina teológica precisa, la de la escuela de Deoband, que no exenta de un transfondo político.

Palabras claves: Islam, India, proselitismo, sufismo, politica. 